\title{
ESTABLISHMENT AND CURRENT STATE OF SCHOOL PSYCHOLOGICAL SERVICES IN AZERBAIJAN AND TURKEY
}

\author{
Harun O. H., \\ Odlar Yurdu University, Baku, Azerbaijan
}

DOI: https://doi.org/10.31435/rsglobal_ws/30062020/7122

ARTICLE INFO
Received: 17 April 2020
Accepted: 13 June 2020
Published: 30 June 2020
KEYWORDS
school psychologist,
school psychologist's professional
qualities,
education,
self-awareness.

\section{ARTICLE INFO}

self-awareness.

\begin{abstract}
The development of psychology in Azerbaijan is closely linked with the opening of the first higher education institutions in the country since the 1920s. In 1919, Baku State University, the first higher education institution in the republic, and in 1921, the first Pedagogical Institute were established. Departments of pedagogy and psychology and the first psychology laboratories were established in these universities. The first psychology laboratory in the country was organized in 1926 under the leadership of prominent psychologist F. Ibrahimbeyov at Baku State University, where psychological devices such as chronoscope, tachistoscope, visual adaptometer, audiometer, ergograph, etc. were installed.

The development of psychology as a science in our republic began in the 20 s and 30 s of the last century, and at that time there were no national psychologists. Therefore, Russian scientists, Azerbaijani philosophers, pedagogues and neurologists taught psychology in the newly opened universities. Among them, the services of A.O. Makovelsky, A.K. Zakuzade, F.A. Ibrahimbeyov, H.B. Shakhtakhtinski, S.N. Hajiyev, V.I. Mustafayev and others should be especially noted.
\end{abstract}

Citation: Harun O. H. (2020) Establishment and Current State of School Psychological Services in Azerbaijan and Turkey. World Science. 6(58), Vol.3. doi: 10.31435/rsglobal_ws/30062020/7122

Copyright: (C) 2020 Harun O. H. This is an open-access article distributed under the terms of the Creative Commons Attribution License (CC BY). The use, distribution or reproduction in other forums is permitted, provided the original author(s) or licensor are credited and that the original publication in this journal is cited, in accordance with accepted academic practice. No use, distribution or reproduction is permitted which does not comply with these terms.

Introduction. One of the main areas of application of psychological knowledge in Azerbaijan and Turkey was, first of all, school experience. For multifaceted research in the field of child psychology and pedagogical psychology with the Azerbaijani educational traditions, the study of psychology in school practice has always been a fundamental point. Systematic research of prominent Azerbaijani psychologists on both age and pedagogical psychology is of great importance for school practice. However, there is a unique technology for applying psychology to school practice.

Many teachers faced the paradox of "creativity" when mastering this technology. There are deep-rooted "language barriers" in this area. Academic language was formed in psychology, and serious difficulties arose in its practice. This aspect was clearly felt in world psychology. Ways of applying different theories, such as psychoanalysis, to school practice were explored. At this root "psychoanalytic pedagogy" appeared. In the 1960s, psychopedagogy, which was important for school practice, was formed as a separate scientific direction. One of the main ways of applying psychology to school practice is related to the pedagogy of psychological paragrams. In the context of democratization and humanization of the Azerbaijani education system and the implementation of new educational reforms, psychological services, the development of children's abilities (pupils, students), individual characteristics, increasing the effectiveness of education, the right way of life, all this are based on ethnopsychological basis. The work of psychological services in schools and other educational institutions helps to optimize the psychological system as a whole, educational work, labor relations in the team and its management. It provides protection, prevention, diagnosis and correction 
of the psychological health of the pedagogical and technical staff of each participant of the education system, parents of children, pupils and students. Significant progress has been made in our country in the context of the theory and practice of psychological services. The content and system of psychological enlightenment, psychological consultation, psychodiagnostics, etc. should be determined by scientific and methodological criteria, and special attention should be paid to the creation of the original "school psychological model". Psychological services in Azerbaijani schools have specific features. Improving the theory and practice of psychological services in secondary schools based on the criteria of the modern concept of education is a key condition for improving the quality of the educational process and its organization.

In 1957, Azerbaijani scientists for the first time prepared and published a dictionary entitled "Terms of pedagogy and psychology." It should be noted that the first experimental work on the psychological characteristics of preschool children in our country was created in 1949 by the Azerbaijani female psychologist M.N. Mustafayeva. This work, called the development of vocabulary in Azerbaijani children of kindergarten age, was the result of the author's dissertation research. The main focus of research in the field of age and pedagogical psychology in 1960-1980 was on their shoulders. As a result of all this, a number of original textbooks and teaching aids, monographs and books were written and published in Azerbaijan in those years. Among them are Sh.S. Agayev's "Issues of child psychology" (B.1966), "Labor, education and development" (B.1967), M.A. Hamzayev's "Management of children's games in the family" (B .1965), AA Alizadeh's "Education of attention in children" (B.1963), "Education of friendship" (B.1964), AS Bayramov's "Development of thinking in students" (B.1962), Z.M. Mehdizadeh's books "Development of thinking and speech in children" (B.1966) and others can be shown.

At the end of the 80s of the last century, began the period of organization of psychological services in the education system. The issue of opening courses for the training of practical psychologists was raised. Preparatory work for these courses was carried out in different directions. From this point of view, the following issues had a special meaning:

1. Development of the curriculum of the course;

2. Selection of listeners from the leading teachers of Baku;

3. Selection of experienced psychologists to conduct lectures and seminars.

The curriculum of this course, prepared by practical psychologists, clearly shows the features of the professional activity of a practical psychologist and is directed to the requirements of the "Regulations". The content of the program for the training of practical psychologists was published in 1984, and the draft "Regulations" provides for the training of these personnel for 2 years. However, the need to provide Baku schools with qualified practical psychologists took a short time, and the optimal solution was to create 6-month refresher courses.

The curriculum of the six-month courses includes the subjects provided for in the regulations general psychology, age psychology, pedagogical psychology, social psychology, psychodiagnostics and basics of psychocorrection, etc. The organization of psychological services in the education system of the Republic of Azerbaijan began about 20 years ago. Regulations on Psychological Service in the Public Education System, prepared in 1988 by the Scientific Research Institute of General and Pedagogical Psychology of the USSR PEA and edited by I.V. Dubrovina in 1989, translated into Azerbaijani in 1990 was delivered to the educational institutions of the Republic. This "Regulation" was republished for the second time in 1999. The regulation consists of 6 sections. The first section, entitled General Provisions, states that school psychological services are an essential part of the education system. Psychological service allows to increase the effectiveness of the school's educational work and the formation of a socially active personality. Here, the work of psychological services in the education system reflects a whole system consisting of 3 main chapters.

1. Practical child psychologist in an educational institution.

2. Psychological cabinet of district, city education department and departments.

3. Psychological service center of education in the republic.

Psychological services are inherently closely related to the types of medical and defectological services. The psychologist must be able to coordinate his / her activities with the opinion and interests of the guardianship and trusteeship bodies of public organizations and to build their relations with these institutions on the basis of equality and complementarity of positions. 
The implementation of practical psychological services in the education system in the "Regulations" covers 4 main areas: Psychoprophylactic work; Psychodiagnostic work; Developmental and psychocorrectional work; Consulting work.

The regulations assess psychoprophylactic work as one of the main directions of the psychological service system. The tasks of psychoprophylactic work are determined by the need for psychological knowledge in educators and children, the need to form in them the desire to use this knowledge for self-development, to create conditions for the comprehensive mental development of the child at any age, to prevent possible disorders.

One of the most important and complex areas of activity of a practical psychologist is called psychodiagnostic work. The "Regulations" provide a system of work on psychodiagnostics, and the following tasks are specifically set before the work to be carried out in this direction.

1. If necessary, to determine the course of the child's mental development, the conformity of development to the age norms through diagnostic examination methods;

2. To ensure an individual approach in the process of educational work, to assist in the development of students' opportunities for professional and personal self-determination, to reveal the level of development of their interests, inclinations and abilities;

3. To diagnose children's communication with adults and peers, to determine the psychological causes of communication disorders;

4. Identification of disorders of medical and defectological nature together with specialists of the relevant profile.

5. Identification of forms and causes of social behavioral disorders, implementation of differential diagnosis of various deviations in mental development.

The section of the statute, called developmental and correctional work, contains a brief summary of the work to be carried out by the practical psychologist in this direction and the measures to be taken. A psychologist working in this direction should have an active position in influencing the formation of individual characteristics of the child's personality.

The professional activity of a school psychologist has a specific content in the direction of consultative work.

Must achieve the following specific responsibilities set out in the Regulations:

1. In the solution of problems related to the education and upbringing of children, cooperation pedagogy, the management of the institution, teachers, educators, parents, etc. providing advice;

2. Training, development, professional and life self-determination, mutual relations, selfeducation, etc. individual and group counseling for children on problems;

3. To help raise the psychological culture of teachers, educators, parents and community members through the use of various forms of work;

4. To provide psychological analysis of the educational conditions in children's educational institutions, various children and youth associations and organizations, to provide advice on the issues of facilitation of work, organization of self-government.

It should be noted that the "Regulations on psychological services in the education system" is the most important document related to the professional activity of a practical child psychologist. In order to effectively build his work, a practical psychologist working in the education system must first of all have a deep knowledge of this important document and be guided by its requirements in his professional activity.

Psychology has always developed in connection with training, education, school. These relations were carried out in various forms: - through psychology textbooks - through scientific methods, articles, dissertations - through scientific laboratories opened in the scientific centers subordinated to it in the education system, especially in schools - through the ideas and works of European psychological schools in this field with research and promotion, etc. Such measures, both theoretically and practically, have greatly contributed to the effectiveness of education.

The implementation of psychological services in Turkish schools has greatly contributed to the effectiveness of education, upbringing and training in the country. Thus, the optimization of teaching in schools, the study of teacher-student relations, the formation of students' learning interests and the emergence of psychological services in the successful implementation of other pedagogical activities are explained by facts, the essence is explained, attention is paid to areas of need in modern times. 
The concepts of "psychological assistance", "psychological counseling", and "psychological service" have entered and developed in the Turkish education system since 1926.

Many psychological service centers have been established. Between 1950 and 2013, the number of these centers in Turkey reached 212. Such events greatly contributed to the quality of the training content. This change (especially "student-centered education") was seen as an important milestone in the Turkish education system. The idea of such an approach to education necessitated the application of so-called "student personality services", counseling, psycho-counseling, psychological assistance, psycho-correction in school practice. Taking into account the nature of psychological services in schools, Turkish psychologists have begun to implement a number of measures in this direction. Psychological service in school mainly begins in primary school. At this age, children develop learning habits. At this age, children enter a new learning environment and interact with teachers. In connection with learning activities, they develop cognitive processes (feelings, perceptions, memory, thinking, imagination, feelings, etc.). The foundation of all future knowledge, skills and habits is laid at this age.

At this age, understanding others, interpersonal relationships, self-awareness, communication, learning habits and other psychological qualities are formed. It is very effective in affective and social development. Therefore, the teacher has advanced guidance. Teachers who teach them must have a broad understanding, and the school psychologist must create an environment. First of all, the child should be able to get acquainted in primary education and through family, friends and relatives.

They gather information from around and get used to the school environment. Students acquire effective work methods, planned work habits, time management and concentration skills, and acquire relevant interest skills. It is important to have knowledge about their interests and needs and to direct them to a certain profession. Talented children should be selected at this age. The organization of education in appropriate conditions is one of the main tasks of the psychological service. Secondary education should also be in the spotlight in this regard.

The high school age period mainly covers adolescence. During these ages, adolescence should be a particular focus. During this period, young people are brought in both physically and during adolescence, while trying to cope with emotional, social and cognitive changes, they also face individual and group problems, academic and professional concerns. Many subjects are taught in secondary schools. Under the influence of these subjects and the teaching process, they develop a new scientific worldview.

At a time when the social development of students is accelerating, the head of the school psychologist must also change. In this process, cooperation programs are promoted. It should be noted that the educational institutions where the "school spirit" is most felt are secondary schools. Students are more social and lively. They need to be more motivated to meet their needs to live together with the social activities in which they participate and to increase their academic success to provide motivation.

Psychologists have used best practices in the field of psychological services in schools in the Turkish education system. Specialists from the United States, France, England, Russia, Spain and other foreign countries were invited. Such attention to psychological services in Turkish schools has helped to form students' learning interests and motives. There is not enough effort in schools to develop communication and interaction.

However, close collaboration must be ensured between the teacher, principal, parent and child to understand students and their needs. As noted in the report prepared by the Istanbul Committee: - It is important that the family and the school cooperate in the development of the child. - All students should participate in extracurricular activities. In these lessons, teachers should be in the role of supervisor. -According to the Istanbul report, it is recommended to hold the last hour of each day on Wednesday and Saturday afternoon.

However, it would be better to dedicate the first hour in the afternoon to these lessons instead of the last hours.

- Leadership activities in primary schools should be carried out by class teachers.

- It should be implemented in secondary schools as recommended by the committee. Throughout school life, the guide teacher gives students knowledge and skills.

- Schools guide them as an educational institution. 
Istanbul, Ankara, Konya, Izmir, Samsun, Adana and other pilot schools, increased attention to psychological services. Very good activities were carried out in the field of psychological services in these schools. However, these schools did not have a systematic and well-established guidance program.

It would be better to appoint a psychologist according to the number of students in order to provide quality psychological services at school. In order to be successful in school, school psychologists need to get to know the student and deal with his or her real needs and problems. Turkish psychologists work closely with US psychologists, invite specialists from there and create courses. During his 125-day short visit to the American Tompkins, who arrived in Turkey on October 23, 1952, he lectured on 125-day courses organized in secondary schools and conducted similar work in 97 other schools.

Psychological services in Turkish schools can be considered as a period of revival before the 1950s.

Psychologists from France, Russia, Italy, Bulgaria, Germany, the United States and the United Kingdom have made a number of recommendations regarding the psychological services of primary and secondary school students at school. American psychologists S. Hall, Kettel, German psychologist A. May, Swiss psychologist E. Klanara, English psychologist F. Haltan, Russian psychologist K.N. Kardov, B.M. Bekhterev, P.P. Blovunsky benefited from the recommendations of L.S. Vygotsky in the field of psychological services at school. On March 3, 1924, the schools entered a new phase by the decision of the Ministry of Education.

In 1926, a secular education system was established, established by Law No. 789 of March 22, 1929 , based on the principles of the Republic.

In 1926, by the decision of the Ministry of Education, with the help of Turkish and foreign psychologists, major changes were made in the curricula of secondary schools in order to improve the situation of psychological services in Turkish schools.

The school developed a program of psychological services and received feedback from relevant agencies. In 1927, some changes were made in all primary schools, and a system of psychological services was established in accordance with these changes. A book on psychological services has been compiled in primary schools, theoretical programs have been developed, and a regulation program has been created that takes into account the principles by which a child can learn his duties as required for life and homeland preparation. This program takes into account the individual interests of students. The goals of the psychological service were defined and the methods of using the materials in this direction were taught.

As a result, a lot of work was done in Turkey between 1920 and 1950 on psychological services at school. During these years, psychology has set foot in schools. This process began in the early 1920s and 1950s and continued in the following years. School-Family Associations were established. As a result of this development, the Ministry of National Education signed the "Regulations on School-Family Association". The idea of psychological services in Turkish schools has already arrived and strengthened its position.

Psychological services to schools in the Turkish education system continue in accordance with previous traditions. The number of psychological centers in schools is increasing, special attention is paid to the professional qualities of school psychologists. In the 2001-2002 academic year, the number of school psychologists working in primary school was 3,157 for 3,725 secondary schools. The number of psychological service centers in schools has been increased and successful results have been achieved in this area.

One of the important tasks of a school psychologist is to take care of the mental health of students. Undoubtedly, mental health affects the teaching, education, morals and thinking of schools as a whole. Mental health (sometimes called mental health) is a condition that protects mental homeostasis (neutrality) from the stresses of solving ordinary life problems that contribute to the realization of a person's spiritual potential, increases the productivity of human life and work, as well as provides spiritual comfort. Mental health is the attitude of a person towards himself and the people around him in general, towards various events, social and economic hardships throughout his life.

Studies show that the need for mental health is most common in schoolchildren aged 13-18. Psychological tensions are an example of this. Behavior, mood disorders, suicidal loneliness, smoking, alcoholism, drug addiction, depression, stress, lack of self-confidence, etc. Almost half of school children have behavioral disorders and stressful situations, which should always be in the focus of the school psychologist. Psychologists from the United States, Turkey, Azerbaijan and other countries 
have conducted serious research in this area and obtained interesting results - American psychologists have learned that suicide among schoolchildren has its own characteristics.

The experiments conducted by Turkish psychologists to obtain information about the state of mental health services at school are also of interest.

A selection survey was conducted by Turkish psychologists to test children with behavioral problems. The study included all young people above a certain cut-off point, as well as $10 \%$ of young people in the lower grades. The result of this process was 136 young people, of whom 1,073 (80\%) participated in the study. The results showed that over three years, assessments of the population showed that $33.6 \%$ received services from one or more of the five service sectors to address emotional behavioral problems or psychoactive substance use problems. Services were mostly provided by the education sector $(24.1 \%) .14 .2 \%$ of the population used special mental health services.

About $11 \%$ of young people use educational services and $7 \%$ use specialized psychiatrists. Services $4 \%$ used general health services, $1 \%-2 \%$ used child welfare or juvenile justice services. Services in the education sector are the most common (42\%), followed by specialized mental health services $(24 \%)$, general medical services (15\%) and children's health or juvenile justice services (4\% $7 \%)$. The education sector was the most common place for all age groups.

\section{REFERENCES}

1. A.F. Bakshaliev - Formation, development and current state of psychological thought in Azerbaijan. Baku 2007

2. Chalabiev N.Z. Psychodiagnostic issues. B., ADPU, 2003

3. Chalabiev N.Z. Clinical indicators of retardation in training and opportunities for correction. Baku, 2005.

4. Alizada A.A. Psychological problems of modern Azerbaijani school. B., Pedagogy, 2004.

5. Amrahli L.S. Basics of psychological services. Development B., 2006.

6. H. Sevgi Yakın, H. Seyma Komurcu - Creativity in the process of psychological counseling and counseling 2018.

7. Basic Topics in Psychological Counseling Applications 2017. 